\title{
INSECTICIDAL AND ANTIMICROBIAL ACTIVITY OF TRIARYL ANTIMONY(V) DERIVATIVES
}

\author{
Ram Nath Prasad Yadav \\ Department of Chemistry, TU, Thakur Ram Multiple Campus, Birganj, Nepal \\ E-mail: ramnathy@rocketmail.com
}

\begin{abstract}
This paper is devoted to the biological activity of the triaryl antimony $(V)$ derivatives which deals with insecticidal and antimicrobial activity of tris(pentafluorophenyl)antimony $(V)$ amides, $(R f)_{3} S b L 2\left(R f=C_{6} F_{5} ; L=N R 2\right.$ : and triaryl antimony $(V)$ carboxylates, $A r_{3} S b L 2\left(A r=C_{6} H_{5}, p-C_{3} C_{6} H_{4} ; \mathrm{L}\right.$ $=$ OCOR. All the compounds were found to exhibit moderate to significant biological activity against P. americana (insect), P. auriginosa, S. Aurens and K. Pneumoniae (bacteria), Synnhemp Rosette (virus), Tobacco Mosaic (Virus) and A. niger, A. flavus and E. moniliforme (Fungus). The compounds with fluoro and amide groups are highly active than that of compounds with phenyl, tolyl and carboxylate groups.
\end{abstract}

\section{Keywords}

Tryarylantimony(V) derivatives; Insecticidal; Antimicrobial; Fluoro; Amide; Carboxylate; Tolyl

\section{Introduction}

Organoantimony compounds (bearing phenyl and p-tolyl group) particularlycarboxylateand $\mathrm{Sb}-\mathrm{N}$ bonded derivatives have recently shown promise to be used as antimicrobial agents. (7-8). Recently, tetraarylstibonium complexes have been reported by Premraj et al.(Premraj et al. 1984) to exhibit siginificant biological activity. Triarylantimony(V) derivatives of various amides and carboxylates have also been reported to possess antibacterial, antifungal, antiviral and insecticidal activity, by Kirran Singhal et al.(Singhal et al.1987). Above findings encouraged up to undertake a systematic study on antimicrobial activity of a variety of organoantimony compounds, particularly Sb-N (amides) and Sb-O (carboxylate) bonded compounds. An added advantage with pentafluorophenyl derivatives is that they are water and lipid soluble and are easy to administer.

Thebiocidalactivityof tertiaryarylantimony(V) derivatives have been studied scarcely so far and there seems to be no published data on the antitumour activity of such compounds. It was, therefore considered worthwhile to examine the biological activity of some representative compounds. The investigation also aims to finding the ways to reduce the toxicity and enhance the activity by improving the design of these analogs by incorporating different organic species. 


\section{Results and discussion}

The insecticidal, antibacterial, antiviral and antifungal screening results of $\mathrm{Ar}_{3} \mathrm{SbL}_{2}$ $\left(\mathrm{Ar}=\mathrm{C}_{6} \mathrm{~F}_{5}, \mathrm{C}_{6} \mathrm{H}_{5}, \mathrm{p}-\mathrm{CH}_{3} \mathrm{C}_{6} \mathrm{H}_{4} ; \mathrm{L}=\mathrm{NR}_{2},-\mathrm{OCOR}\right)^{3}$ was carried against three fungi and three bacteria together with their antiviral activity. Compounds selected were those containing $\mathrm{Sb}-\mathrm{N}$ and $\mathrm{Sb}-\mathrm{O}$ bond.

\section{Insecticidal activity}

Insecticidal activity of the tertiary aryl antimony $(\mathrm{V})$ derivatives was carried out against the insect Periplanata Americana. Compounds are moderately effective against Periplanata Americana and activity is significantly affected by the nature of the aryl group. It shows the compounds with fluoro and amide groups are highly active than that of compounds with phenyl, tolyl and carbooxylate groups. When amide substituted compounds are injected into the test cockroaches, the insect fall on the backs after 4-5 h. This is followed by kicking of legs, convulsions of abdomen and flickering of antennae for about 8-18 h varying in different compounds of the series, the Knock down or moriband state is reached between 10-24 and 7-22 h. for 0.1 and $0.5 \%$ concentration, respectively. Compounds subsituted with fluoro group and amide moieties, $\left(\mathrm{R}_{\mathrm{f}}\right)_{3} \mathrm{Sb}\left(-\mathrm{NCOCH}_{2} \mathrm{CH}_{2} \mathrm{CO}\right)_{2},\left(\mathrm{R}_{\mathrm{f}}\right)_{3} \mathrm{Sb}\left(-\mathrm{NCOC}_{6} \mathrm{H}_{4} \mathrm{CO}\right)_{2}$, $\left(\mathrm{R}_{\mathrm{f}}\right)_{3}\left(-\mathrm{NCOCOC}_{6} \mathrm{H}_{4}\right)_{2},\left(\mathrm{R}_{\mathrm{f}}\right)_{3} \mathrm{Sb}\left(-\mathrm{NC}\left(\mathrm{CH}_{3}\right) \mathrm{NCHCH}\right)_{2}$ $\left(\mathrm{R}_{\mathrm{f}}\right)_{3} \mathrm{Sb}-\left(-\mathrm{NC}\left(\mathrm{CH}_{2} \mathrm{Cl}\right) \mathrm{NC}_{6} \mathrm{H}_{4}\right)_{2}$ are active against Periplanata Americana than those complexes substituted with phenyl group and carboxylate moities; where as $\mathrm{Ph}_{3} \mathrm{Sb}\left(\mathrm{OCOCH}_{2} \mathrm{NHCOC}_{6} \mathrm{H}_{5}\right)_{2}$, (p-toly) Sb- $_{3}$ $\left(\mathrm{OCO}(\mathrm{OH})_{3} \mathrm{C}_{6} \mathrm{H}_{2}\right)_{2}, \quad \mathrm{Ph}_{3} \mathrm{Sb}\left(\mathrm{OCOC}_{6} \mathrm{H}_{5}\right)_{2}$ and (p-toly) ${ }_{3} \mathrm{Sb}\left(\mathrm{OCO}(\mathrm{OH}) \mathrm{C}_{6}^{3} \mathrm{H}_{4}\right)_{2}$ show almost higher activity than the parent compound viz. $\mathrm{Ph}_{3} \mathrm{SbCl}_{2}$ and (p-tolyl) $\mathrm{SbCl}_{2}$ (Fig. 1).

\section{Antimicrobial activity}

\section{Antibacterial activity}

Disc diffusion method was used for determination of antibacterial activity against Pseudomonas auriginosa, Klebselia pneumonia and Staphylococcus aurens. Nine compounds of the series were assayed for this purpose.

The antibacterial screening of the given compounds shows that the fluoro group amide substituted compounds are highly active against Pseudomonas auriginosa $\underline{\mathrm{K}}$. pneumonia and also on S. aurens. Compounds with salicylic acid, benzoic acid were least active against all the three strains of bacteria. The all rest compound with hippuric acid and gallic acid were found moderate active against the bacterial strains (Table 1 ).

\section{Antiviral activity}

Seven compounds were subjected for their antiviral activity. The results indicate that the compounds with succinimide, 2-chloromethyl benzimidazole, isatin, hippuric acid, gallic acid are moderately active against Synnhemp Rosette Virus (SRV) from $\underline{\text { Cyamosis }}$ tetraqnoloba plants and Tobacco mosaic virus (TMV) from Nicotiana glutinosa plant both in-vitro and in-vivo.

Irrespective of the nature of ligand and aryl group attached to the antimony atom, complexes in general were found to have moderate to significant activity against both the virus. Compounds with fluoro group and amido ligand show higher activity than the compounds with phenyl group and carboxylates both in-vitro and in-vivo.

From the data presented in table (2). It can be seen that the tris (pentafluorophenyl) antimony $(\mathrm{V})$ 2-chloromethyl dibenzidmidazole was found to be most active against SRV while in case of tris(pentafluorophenyl) antimony $(\mathrm{V})$ diisatin showed the maximum inhibition. It was clear that the compound having phenyl and carboxylate group did not show satisfactory inhibition both SRV and TMV.

In vitro at the compounds showed better inhibition both against SRV and TMV than in-vivo. 
Notable feature is that the presence of 2-methyl imidazole moiety diminishes the inhibiting power of the compounds upto very low level but when 2-methyl imidazole moiety was replaced by 2-chloromethyl benzimidazole it increases the percentage inhibition upto 55-70.

\section{Antifungal activity}

The antifungal screening results (Table 3) indicates that compounds with imide moieties viz: succimide and phthalimide and carboxylate moieties viz. hippuric acid and gallic acid are moderately active against Aspergillus niger. Aspergillus flavus and Fusarium moniliforme.

Besides this, it is also apparent from the data listed in table 3 that fluorophenyl antimony compounds are more active than there phenyl analogs. Among the imides, compound having succinimide moiety is moreactive against the $\underline{A}$. niger and $\underline{F}$. moniliforme whereas phthalimide moiety is more active against $\underline{\mathrm{A}}$. flavus.

Tris (pentafluorophenyl)antimony (V) discuccinimide has been tested against $\underline{\text { A. niger }}$ and $\underline{\mathrm{F}}$. moniliforme and found to be more active whereas against $\underline{A}$. flavus, tris (pentafluorophenyl)antimony (V) diphthalimide was found to be very active.

Triphenylantimony(V) dihippurate is more active against $\underline{\mathrm{A}}$. niger and $\underline{\mathrm{A}}$. flavus whereas tri(p-tolyl)antimony $(\mathrm{V})$ digallate are equally more active against $\underline{\mathrm{F}}$. maniliforme.

So, in general, presence of perfluorophenyl containing with antimony compounds seems to enhance the antifungal activity.

\section{Experimental}

\section{Insecticidal testing}

The insecticidal activity of these compounds was determined against male and female adult cockroaches (Periplanata Americana) following the method of Nash(Nash 1954) using parathion as standard $0.2 \%$, of $0.1 \%$ and $0.5 \%$ acetonic solution of the compounds were injected between $4^{\text {th }}$ and $5^{\text {th }}$ abdominal segment on the ventral side of the body, with the help of micro syringe and $0.02 \mathrm{ml}$ of acetone was alone injected for control. The treated insects were kept under observation for $48 \mathrm{~h}$ at room temperature. (No food was given in the period). The average knock down (K.D.)/hr value was taken to assess the activity.

\section{Antibacterial testing}

Antibacterial activity of these compounds was determined by disc diffusion method. In this methods (Verma \& Imam 1973) the filter paper (Whatmann No. 1) sterile discs of $5 \mathrm{~mm}$ diameter, impregnated with the test compounds (10 $\mathrm{mg} / \mathrm{ml}$ of ethanol) were placed on the nutrient agar plate at $37^{\circ} \mathrm{C}$ for $24 \mathrm{~h}$. The inhibition zones around the dried impregnated discs were measured after $24 \mathrm{~h}$.

The activity was classified as "highly active" (diameter $=>15 \mathrm{~mm}$ ) "moderately active" (diameter $=10-15 \mathrm{~mm})$, and "slightly active" (diameter $=6-10 \mathrm{~mm})$. The diameter less than $6 \mathrm{~mm}$ was regarded as inactive. All the compounds were tested in triplicate.

\section{Antiviral testing}

Antiviral activity of the compounds was evaluated against Synnhemp Rosette Virus (SRV) from Camposis tetragonoloba plants and Tobacco Mosaic Virus (TMV) from Nicotiana glutinosa plant both in vitro and in vivo.

The culture of SRV/TMV was maintained by successive host inoculations. The virus inoculum was prepared by grinding $5 \mathrm{~g}$ of fresh leaves, showing severe disease symptoms, using a sterilized pestle and mortar. With an equal amount of distilled water $(w / v)$. The pulp was squeezed through two layers of muslin cloth, and the juice was centrifuged at $5000 \mathrm{~g}$ for $15 \mathrm{~min}$. The resulting partially clarified supernatent and diluted (1:100) with distilled water and used for virus inoculation.

The solution of test compounds were prepared by dissolving $10 \mathrm{mg}$ in $1 \mathrm{ml}$ of ethanol and 
making up the volume to $10 \mathrm{ml}$ with distilled water. These solutions were formed as test solutions.

For in-vitro studies, $1 \mathrm{ml}$ of test solution was mixed with $1 \mathrm{ml}$ of virus suspension and the mixture left $15 \mathrm{~min}$. at room temperature $\left(27^{\circ} \mathrm{C}\right)$, then spread over leaves of $\underline{\mathrm{C}}$ tetragonoloba $/ \underline{\mathrm{N}}$. glutinosa plants. An equal number of leaves were rubbed with a mixture of virus and distilled water and served as controls.

For in-vivo experiments, the test solutions were applied on to the upper surface of leaves of $\underline{\mathrm{C}}$. tetragonoloba/N. glutinosa plants, $24 \mathrm{~h}$ prior to virus challenge. The leaves of control plants were treated in the same way with a mixture of $1 \mathrm{ml}$ of ethanol and $9 \mathrm{ml}$ of distilled water. At least five plants, with four leaves being of about equal size were used in each experiment.

All experiments were performed in an insect-free glass house kept at about $25-30^{\circ} \mathrm{C}$. Phytotonic symptoms, if any, were observed through out the experiment period. Local lesions were counted after 3-4 days of virus inoculation. The present inhibition was expressed as

$$
\frac{C-T}{C} X 100
$$

where,

$\mathrm{C}=$ number of local lesions on control

$\mathrm{T}=$ number of local lesions on treated leaves.

\section{ANTIFUNGAL TESTING}

Antifungal activity was carried out against $\underline{\text { Aspergillus niger, }}$ aspergillus flavus and Fusarium moniliforme at $100 \mathrm{ppm}$ concentration. The number of replication in each case was three. For antifungal testing the sterilized potato-dextrose agar medium (Riker \& Riker 1936) (20 ml) was melted and cooled to $45^{\circ} \mathrm{C}$. Known quantity of the test compound in acetone $(2 \mathrm{ml})$ was mixed with medium and poured into petridis $(12.5 \mathrm{~cm}$ in diameter). The test organism was inoculated with test compound and incubated at $27^{\circ} \mathrm{C}$ for $96 \mathrm{~h}$. The percentage protecting by various compounds was calculated by the formula (Giri \& Khare 1976).

$P$ rotection $\%=\frac{C-T}{C} \times 100$

$\mathrm{C}=$ Diameter of Fungus colony in control plate.

$\mathrm{T}=$ Diameter of Fungus colony in treated plate.

Table-1 : Antibacterial activity of triarylantimony(v) derivatives

\begin{tabular}{|c|c|c|c|c|c|}
\hline S. No. & Compound & P. auriginosa & S. aurens & K. pneumonae & Control \\
\hline 1. & $\left(\mathrm{C}_{6} \mathrm{~F}_{5}\right)_{3} \mathrm{Sb}\left(-\mathrm{NCOCH}_{2} \mathrm{CH}_{2} \mathrm{CO}\right)_{2}$ & +++ & +++ & +++ & - \\
\hline 2. & $\left(\mathrm{C}_{6} \mathrm{~F}_{5}\right)_{3} \mathrm{Sb}\left(-\mathrm{NCOC}_{6} \mathrm{H}_{4} \mathrm{CO}\right)_{2}$ & +++ & ++ & +++ & - \\
\hline 3. & $\left(\mathrm{C}_{6} \mathrm{~F}_{5}\right)_{3} \mathrm{Sb}\left(-\mathrm{NCOCOC}_{6} \mathrm{H}_{4}\right)_{2}$ & +++ & +++ & +++ & - \\
\hline 4 . & $\left(\mathrm{C}_{6} \mathrm{~F}_{5}\right)_{3} \mathrm{Sb}\left(-\mathrm{NC}\left(\mathrm{CH}_{3}\right) \mathrm{NCHCH}\right)_{2}$ & ++ & +++ & ++ & - \\
\hline 5 . & $\left(\mathrm{C}_{6} \mathrm{~F}_{5}\right)_{3} \mathrm{Sb}\left(-\mathrm{NC}\left(\mathrm{CH}_{2} \mathrm{Cl}\right) \mathrm{NC}_{6} \mathrm{H}_{4}\right)_{2}$ & +++ & ++ & ++ & - \\
\hline 6. & $\left(\mathrm{C}_{6} \mathrm{H}_{5}\right)_{3} \mathrm{Sb}\left(\mathrm{OCOCH}_{2} \cdot \mathrm{NHCOC}_{6} \mathrm{H}_{5}\right)_{2}$ & ++ & + & + & - \\
\hline 7 . & $(p \text {-tolyl })_{3} \mathbf{S b}\left(\mathbf{O C O}(\mathrm{OH})_{3} \cdot \mathrm{C}_{6} \mathbf{H}_{2}\right)_{2}$ & ++ & + & ++ & - \\
\hline 8. & $\left(\mathrm{C}_{6} \mathrm{H}_{5}\right)_{3} \mathrm{Sb}\left(\mathrm{OCOC}_{6} \mathrm{H}_{5}\right)_{2}$ & + & + & + & - \\
\hline 9. & $(p \text {-tolyl })_{3} \mathrm{Sb}\left(\mathrm{OCO}(\mathrm{OH}) \mathrm{C}_{6} \mathrm{H}_{4}\right)_{2}$ & + & ++ & + & - \\
\hline
\end{tabular}

- = control (inactive) $;+=$ zone size 5-10 $\mathrm{mm} ;++=$ zone size $10-15 \mathrm{~mm} ;+++=$ zone size $>15 \mathrm{~mm}$ 
Ram Nath Prasad Yadav

Table-2: Antiviral activity of triarylantimony(v) derivatives

\begin{tabular}{|c|c|c|c|c|c|}
\hline \multirow{2}{*}{ S. No. } & \multirow{2}{*}{ COMPOUND } & \multicolumn{2}{|c|}{$\begin{array}{c}\text { Percentage inhibition } \\
\text { of SRV }\end{array}$} & \multicolumn{2}{|c|}{$\begin{array}{c}\text { Percentage inhibition } \\
\text { of TMV }\end{array}$} \\
\hline & & In-vitro & In-vivo & In-vitro & In-vivo \\
\hline 1. & $\left(\mathrm{C}_{6} \mathrm{~F}_{5}\right)_{3} \mathrm{Sb}\left(-\mathrm{NCOCH}_{2} \mathrm{CH}_{2} \mathrm{CO}\right)_{2}$ & $44^{\mathrm{a}}$ & $3^{8^{a}}$ & $45^{\mathrm{a}}$ & $33^{\mathrm{b}}$ \\
\hline 2. & $\left(\mathrm{C}_{6} \mathrm{~F}_{5}\right)_{3} \mathrm{Sb}\left(-\mathrm{NC}\left(\mathrm{CH}_{3}\right) \mathrm{NCHCH}\right)_{2}$ & $16^{\mathrm{a}}$ & $9^{b}$ & $11^{b}$ & $6^{\mathrm{b}}$ \\
\hline 3. & $\left(\mathrm{C}_{6} \mathrm{~F}_{5}\right)_{3} \mathrm{Sb}\left(-\mathrm{NCOCOC}_{6} \mathrm{H}_{4}\right)_{2}$ & $69^{\mathrm{b}}$ & $54^{\mathrm{b}}$ & $57^{\mathrm{b}}$ & $45^{\mathrm{a}}$ \\
\hline 4. & $\left(\mathrm{C}_{6} \mathrm{~F}_{5}\right)_{3} \mathrm{Sb}\left(-\mathrm{NC}\left(\mathrm{CH}_{2} \mathrm{Cl}\right) \mathrm{NC}_{6} \mathrm{H}_{4}\right)_{2}$ & $59^{\mathrm{a}}$ & $41^{b}$ & $49^{\mathrm{b}}$ & $47^{\mathrm{a}}$ \\
\hline 5 . & $\left(\mathrm{C}_{6} \mathrm{H}_{5}\right)_{3} \mathrm{Sb}\left(\mathrm{OCOCH}_{2} \cdot \mathrm{NHCOC}_{6} \mathrm{H}_{5}\right)_{2}$ & $40^{b}$ & $37^{\mathrm{a}}$ & $42^{\mathrm{a}}$ & $39^{\mathrm{b}}$ \\
\hline 6. & $(p \text {-tolyl })_{3} \mathrm{Sb}\left(\mathrm{OCO}(\mathrm{OH})_{3} \cdot \mathrm{C}_{6} \mathrm{H}_{2}\right)_{2}$ & $45^{\mathrm{b}}$ & $4^{\mathrm{a}}$ & $4^{a}$ & $35^{\mathrm{b}}$ \\
\hline 7. & $\left(\mathrm{C}_{6} \mathrm{H}_{5}\right)_{3} \mathrm{Sb}\left(\mathrm{OCOC}_{6} \mathrm{H}_{5}\right)_{2}$ & $3^{8^{a}}$ & $33^{\mathrm{a}}$ & $37^{\mathrm{b}}$ & $32^{\mathrm{b}}$ \\
\hline
\end{tabular}

$\mathrm{a}=$ Data significant At $1 \%$ Level; $\mathrm{b}=$ Data significant At 5\% level

Table-3: Antifungal activity of triarylantimony(V) derivatives

\begin{tabular}{|c|c|c|c|c|}
\hline \multirow{2}{*}{ S. No. } & \multirow{2}{*}{ Compound } & \multicolumn{3}{|c|}{ Protection percentage at conc. $100 \mathrm{ppm}$} \\
\hline & & A. Niger & A. Flavus & E. Moniliforme \\
\hline 1. & $\left(\mathrm{C}_{6} \mathrm{~F}_{5}\right)_{3} \mathrm{Sb}\left(-\mathrm{NCOCH}_{2} \mathrm{CH}_{2} \mathrm{CO}\right)_{2}$ & 62.50 & 47.80 & 60.00 \\
\hline 2. & $\left(\mathrm{C}_{6} \mathrm{~F}_{5}\right)_{3} \mathrm{Sb}\left(-\mathrm{NC}_{6} \mathrm{H}_{4} \mathrm{C}_{6} \mathrm{H}_{4}\right)_{2}$ & 38.40 & 36.60 & 40.50 \\
\hline 3. & $\left(\mathrm{C}_{6} \mathrm{~F}_{5}\right)_{3} \mathrm{Sb}\left(-\mathrm{NNNC}_{6} \mathrm{H}_{4}\right)_{2}$ & $34 \cdot 70$ & 36.20 & $34 \cdot 50$ \\
\hline 4 . & $\left(\mathrm{C}_{6} \mathrm{~F}_{5}\right)_{3} \mathrm{Sb}\left(-\mathrm{NCOC}_{6} \mathrm{H}_{4} \mathrm{CO}\right)_{2}$ & 42.20 & 52.00 & $39 \cdot 50$ \\
\hline 5. & $\left(\mathrm{C}_{6} \mathrm{H}_{5}\right)_{3} \mathrm{Sb}\left(\mathrm{OCOCH}_{2} \cdot \mathrm{NHCOC}_{6} \mathrm{H}_{5}\right)_{2}$ & 41.70 & 42.00 & 35.90 \\
\hline 6. & $(p \text {-tolyl })_{3} \mathrm{Sb}\left(\mathrm{OCO}(\mathrm{OH})_{3} \cdot \mathrm{C}_{6} \mathrm{H}_{2}\right)_{2}$ & 33.20 & $32 \cdot 50$ & 34.80 \\
\hline 7. & $\left(\mathrm{C}_{6} \mathrm{H}_{5}\right)_{3} \mathrm{Sb}\left(\mathrm{OCOC}_{6} \mathrm{H}_{5}\right)_{2}$ & $29 \cdot 30$ & 35.80 & 38.30 \\
\hline 8. & $(p \text {-tolyl })_{3} \mathrm{Sb}\left(\mathrm{OCO}(\mathrm{OH}) \mathrm{C}_{6} \mathrm{H}_{4}\right)_{2}$ & 36.70 & 34.20 & 38.80 \\
\hline
\end{tabular}




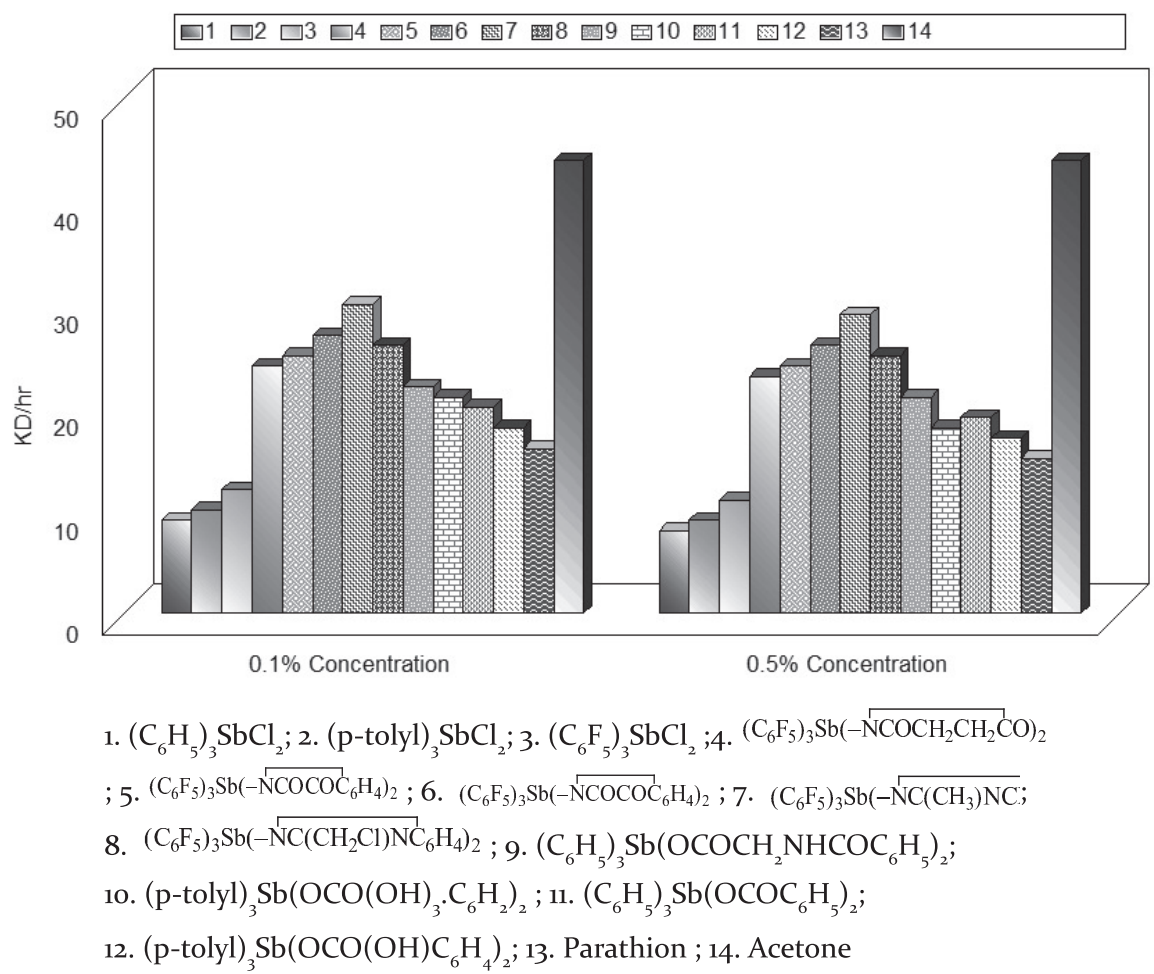

Fig. 1: chart showing insecticidal activity of triarylantimony(v) derivatives

\section{Ackowledgement}

The author is thankful to the Head, Department of chemistry, Lucknow University, for providing necessary laboratory facilities, the director, NBRI, Lucknow for tested insecticidal and antimicrobial activity. Thanks are also due to Dr. Premraj, Professor of chemistry, Lucknow University,Lucknow India for his valuable suggestions.

\section{References}

burrell, R.E., Corke, C.T. \& Goel, R.G. (1983). Fungitoxicity of organoantimony and organobismuth compounds.J. Agri. Food Chem. 31, 85-88.

Giri, S. \& Khare, R.K. (1976). Biological studies of some new amides of sulphosalicylic acid. J. Antibacterial Antifungal Agent. 4, 11-17.

Nash, R. (1954). Studies on the synergistic effect of piperonyl butoxide and isobutylundecyleneamide on pyrethrins and allethrin. Annals of Applied Biology. 41, 652-663.

Premraj, Singhal,K., Ranjan, A. \& Rastogi, R. (1984). Synthesis and characterization of tetraarylstibonium amides, oximates and carboxylates. Synth. React. Inorg. Met-Org. Chem. 14 (2), 269-282.

Riker, A.J. \& Riker, R.S. (1936). Introduction to research on plant disease. New York.

Singhal, K., Rastogi, R., \& Premraj. (1987). Synthesis and biological evaluation of some substituted tertiaryarylantimony(V) derivatives. Indian J. Chem. 26A, 146-150.

Verma, R.S. \& Imam, S.A.(1975). Isatin-3-anils as excystment and cysticidal agents against schizopyrenus russelli. Indian J. Microbial. 31(11), 1287-1288. 